\title{
Antiproliferative activity of tea catechins associated with casein micelles, using HT29 colon cancer cells
}

\author{
S. Haratifar, ${ }^{* 1}$ K. A. Meckling, $†$ and M. Corredig* \\ *Department of Food Science, and \\ †Department of Human Health and Nutritional Sciences, University of Guelph, Guelph, Ontario, Canada N1G 2W1
}

\begin{abstract}
Numerous studies have shown that green tea polyphenols display anticancer activities in many organ sites by using different experimental models in rodents and in cultured cell lines in vitro. The present study tested the ability of casein micelles to deliver biologically active concentrations of polyphenols to HT-29 colon cancer cells. Epigallocatechin gallate (EGCG), the major catechin found in green tea, was used as the model molecule, as it has been shown to have antiproliferative activity on colon cancer cells. In the present work, we hypothesized that due to the binding of caseins with EGCG, casein micelles may be an ideal platform for the delivery of this bioactive molecule and that the binding would not affect the bioaccessibility of EGCG. The cytotoxicity and proliferation behavior of HT-29 colon cancer cells when exposed to free EGCG was compared with that of nanoencapsulated EGCG in casein micelles of skim milk. Epigallocatechin gallate-casein complexes were able to decrease the proliferation of HT-29 cancer cells, demonstrating that bioavailability may not be reduced by the nanoencapsulation. As casein micelles may act as protective carriers for EGCG in foods, it was concluded that nanoencapsulation of tea catechins in casein micelles may not diminish their antiproliferative activity on colon cancer cells compared with free tea catechins.
\end{abstract}

Key words: casein, epigallocatechin gallate (EGCG), nanoencapsulation, HT-29 cancer cells

\section{INTRODUCTION}

In recent years, polyphenols have been recognized as important components in the diet, as their consumption has increasingly been associated with the prevention of various chronic diseases (Yang et al., 2009; González de Mejía et al., 2010; Yuan et al., 2011). Recent epidemiological and clinical data have associ-

Received July 17, 2013.

Accepted October 20, 2013

${ }^{1}$ Corresponding author: sharatif@uoguelph.ca ated green tea consumption with a reduced risk of different types of cancer, diseases of the cardiovascular system, and neurodegenerative diseases (Zaveri, 2006; Wang et al., 2011; Song et al., 2012). Tea (Camellia sinensis), which is the second-most-consumed beverage in the world, is a rich source of extractable polyphenols, more specifically of flavan-3-ols, commonly referred to as catechins. The catechins in green tea represent up to $85 \%$ of the total polyphenols (Ferruzzi, 2010). Major tea catechins include epicatechin, epigallocatechin, epigallocatechin gallate (EGCG), and epicatechin gallate. Epigallocatechin gallate is the major catechin component in tea and it appears to be the most biologically active (Vaidyanathan and Walle, 2003; Du et al., 2012). Among the many beneficial effects of tea polyphenols, its cancer preventive activity has drawn the most attention (Yang et al., 2011). Scavenging of reactive oxygen and nitrogen species, chelating of redox active metals, inhibiting cancer-related transcription factors, and inhibiting oxidative enzymes are among the reactions involving catechins that may result in their beneficial health effects (Green et al., 2007). Various studies have observed that tea polyphenols inhibit tumor formation and proliferation in different cell lines, as well as in animal models (Yang et al., 2006). The inhibitory activity can include decreasing cell proliferation, increasing apoptosis, and suppressing angiogenesis (Araújo et al., 2011).

Bioavailability is usually defined as the fraction of the bioactive constituents (or the metabolites) that have been absorbed by the body and can exert their biological actions at specific target tissue sites. Bioavailability appears to differ greatly among polyphenols, and for tea catechins it is generally considered to be poor (Ferruzzi, 2010; Visioli et al., 2011).Several factors may play a part in limiting the bioavailability of polyphenols, including molecular structure, amount consumed, intestinal absorption, and the degree of bioconversion in the gut (Papadopoulou, and Frazier, 2004; Yang et al., 2008). In addition, the interactions between the bioactive molecules and the food matrix are considered critical factors limiting or enhancing bioavailability (Saura-Calixto et al., 2007). 
Due to the off-taste caused by polyphenols, their enrichment in food products is often limited. However, using food proteins as carriers of polyphenols may reduce this problem (Bohin et al., 2012). Traditionally, in many countries, tea is consumed with the addition of milk to improve the sensory properties (i.e., to reduce the astringency sensation caused by polyphenols; Bennick, 2002; Ferruzzi et al., 2012). Sensory studies have shown that caseins, especially $\beta$-CN, due to their strong binding ability to tea catechins, decrease the sensation of astringency caused by the tea polyphenols (Lesschaeve and Noble, 2005; Hofmann et al., 2006; Schwarz and Hofmann, 2008). Milk is a nutritious source of compounds beneficial to growth and health in children as well as adults. Both whey proteins and caseins can act as delivery vehicles for bioactive compounds. For example, BSA has often been referred to as a carrier of chemotherapeutic drugs in the circulatory system (Livney, 2010). Also, nanoencapsulation with $\beta$-LG has been shown to protect EGCG against oxidative degradation (Shpigelman et al., 2010). Recent studies have also demonstrated the association of bioactive molecules such as resveratrol, vitamin D, and curcumin (a polyphenol) with casein micelles (Semo et al., 2007; Sahu et al., 2008; Rahimi Yazdi, and Corredig, 2012). The encapsulation of vitamin $\mathrm{D}$ in casein micelles provided partial protection against UV-induced degradation of vitamin D (Semo et al., 2007).

Polyphenols are known to have strong affinities to proteins rich in proline and proteins with an open and flexible structure, such as caseins (Bennick, 2002; Papadopoulou, and Frazier, 2004). Studies have shown that the highest extent of binding of catechins to isolated forms of caseins was noted for $\beta-\mathrm{CN}$, followed by $\alpha_{\mathrm{s}}-\mathrm{CN}$ and $\kappa-\mathrm{CN}$ (Luck et al., 1994; Arts et al., 2002). Protein and polyphenol interactions are driven by hydrogen bridging between the phenolic hydroxyl and peptide carbonyl, as well as interactions between hydrophobic amino acid residues and the phenolic rings (Pascal et al., 2008; Ozdal et al., 2013). Recent studies have shown that casein micelles reach saturation with EGCG at around $2.5 \mathrm{mg} / \mathrm{mL}$ (Shukla et al., 2009; Haratifar and Corredig, 2014). It is generally assumed that EGCG is mostly encapsulated within the core of the casein micelles; however, the exact location of the bioactive molecules and the molecular details of the interactions occurring within the casein micelles are not known. Epigallocatechin gallate is certainly present on the surface of the micelles, as at high enough concentrations (above saturation) inhibition of rennet-induced aggregation occurs (Haratifar and Corredig, 2014).

In terms of bioaccessibility of nanoencapsulated polyphenols, researchers have shown that curcumin encapsulated within casein micelles can be efficiently taken up by cell cultures (HeLa cells; Sahu et al., 2008), but no research is available on intestinal cell lines. In addition, the bioaccessibility of polyphenols in milk mixtures is still a source of debate. Some studies have shown that the presence of protein masks the antioxidant capacity of tea catechins (Arts et al., 2002; Kartsova and Alekseeva, 2008). This masking effect was also reported in human clinical trials comparing tea consumed with or without milk (Langley-Evans, 2000). In contrast, other studies indicate no effect exists of milk consumption with tea on the plasma antioxidant capacity of tea polyphenols (Leenen et al., 2000; Keogh et al., 2007; Kyle et al., 2007). The discrepancies between results in these studies may derive from differences in the experimental design and methodologies used (Dubeau, et al., 2010). It is also important to note that the stability of catechins during storage and digestion is often shown to be poor, but this may not be the case in the presence of food matrices (Green et al., 2007; Bazinet et al., 2010; Ferruzzi, 2010).

The objective of this work was to test the effect of nanoencapsulation of EGCG in casein micelles on its cytotoxicity and antiproliferative activity. Casein micelles can load a substantial amount of catechins within their structure, acting as carriers for these bioactive molecules. The antiproliferative activities of EGCG on HT 29 colon cancer cells was tested with free EGCG and EGCG in various milk matrices: namely, milk serum, milk whey, and skim milk. The study of the effectiveness of EGCG on the inhibition of colorectal carcinogenesis is of great interest. The majority of the studies related to the antiproliferative properties of polyphenols on colon cancer cells has so far been based on the effect of individual polyphenols or crude polyphenol extracts (Hong et al., 2002; Chen et al., 2003; $\mathrm{Na}$ and Surh, 2006), and much less has been reported on polyphenols bound to protein structures such as casein micelles. However, gut epithelial cells are more likely to be exposed to complex food matrices, and this, as previously discussed, may affect the bioavailability of polyphenols in the gut (Saura-Calixto et al., 2007).

\section{MATERIALS AND METHODS}

\section{Milk Sample Preparation}

Commercial skim milk was purchased from a local super market (Parmalat Canada Inc., Toronto, ON, Canada). Separation of the soluble proteins (whey) from the casein micelles was accomplished by centrifugation at $36,000 \times g$ for $45 \mathrm{~min}$ at $20^{\circ} \mathrm{C}$ (with rotor type $70.1 \mathrm{Ti}$; Beckman Coulter Canada Inc., Mississauga, ON, Canada) as previously described (Rodriguez del Angel and Dalgleish, 2006). Milk serum (permeate) was 
prepared using a laboratory-scale UF cartridge (Millipore CDUF001LG; Fisher Scientific, Montreal, QC, Canada), with a nominal cutoff of $10,000 \mathrm{Da}$ and a nominal area of $1 \mathrm{ft}^{2}\left(0.095 \mathrm{~m}^{2}\right)$. A polyphenol extract from green tea (containing a minimum of 90\% EGCG) was obtained from DSM Nutritional Products Inc. (Montreal, QC, Canada). Different concentrations of EGCG were obtained from a stock solution of EGCG in water $(20 \mathrm{mg} / \mathrm{mL}$ of water $)$. The $\mathrm{pH}$ of the stock solution was 4.6 and the solution was directly added to milk.

The concentrations of EGCG used in this study for cell exposure were chosen from a previous study on EGCG nanoencapsulation in casein micelles (Haratifar and Corredig, 2014). Those authors determined the amount of EGCG associated with the casein micelles by separating the casein micelles from the whey fraction of milk-EGCG mixtures and then analyzing the whey fraction by reversed-phase HPLC (Ferruzzi and Green, 2006); hence, any EGCG interacting with the whey was included in the fraction recovered in the supernatant and subtracted from the total EGCG, allowing for an estimate of the amount associated with the casein micelles. In brief, aliquots of whey were combined with $2 \%$ aqueous acetic acid $(1: 1, \mathrm{vol} / \mathrm{vol})$ and centrifuged at $14,000 \times g$ for $5 \mathrm{~min}$. Supernatants were collected and filtered through a $0.45-\mu \mathrm{m}$ polytetrafluoroethylene (PTFE) filter and immediately injected. A parallel set of tea catechin solutions containing whey protein isolates (separated from skim milk as described above) were also prepared and were used to produce standard curves to determine the effect of the presence of whey proteins in the quantification of the EGCG.

\section{Cell Viability and Proliferation Assays}

Human colorectal cancer cells (HT-29) were obtained from the American Type Culture Collection (ATCCHTB-38; ATCC, Manassas, VA). The HT-29 cells were maintained in Dulbecco's modified Eagle's medium supplemented with $10 \%$ heat-inactivated fetal bovine serum, $2.2 \mathrm{~g}$ of sodium bicarbonate/L, $1 \%$ penicillin/streptomycin (dual antibiotic solution: 10,000 U/mL), and 1\% L-glutamine (Sigma-Aldrich Canada Ltd., Oakville, ON, Canada), and incubated at $37^{\circ} \mathrm{C}$ in $95 \%$ humidity and $5 \% \mathrm{CO}_{2}$ (Forma Series II Water-Jacketed $\mathrm{CO}_{2}$ Incubator, model 3110; Thermo Fisher Scientific, Waltham, $\mathrm{MA}$ ). The cells grew as monolayers in $25-$ or $75-\mathrm{cm}^{2} \mathrm{~T}$ flasks (Corning Inc., Corning, NY) where the cell culture medium was changed every 48 to $72 \mathrm{~h}$ and cells passed weekly (when 80-90\% confluency was reached) using $0.25 \%$ trypsin containing $0.38 \mathrm{~g} / \mathrm{L}$ of EDTA-4Na (Invitrogen Canada Inc., Burlington, ON, Canada).
Trypan blue dye exclusion was used to determine the viability of the cancer cells when exposed to EGCG and EGCG milk samples. Trypan blue is a vital stain that leaves nonviable cells with a distinctive blue color when observed under a microscope, whereas viable cells appear unstained. The HT-29 colon cancer cells were seeded and allowed to grow for $48 \mathrm{~h}$. Afterward, different concentrations of EGCG (0.2 to $5 \mathrm{mg} / \mathrm{mL}$ of water or milk), alone and in combination with milk, were then added to the cells and incubated for $24 \mathrm{~h}$. Each sample was diluted in medium at a ratio of 1:6 (sample:medium, vol/vol). After $24 \mathrm{~h}$ of incubation with the EGCG and EGCG milk samples, the cells were trypsinized, suspended in culture medium, and counted and measured using Trypan blue dye with a Neubauer hemocytometer (Bright-Line Hemacytometer; Reichert Inc., Buffalo, NY; Ehrich and Sharova, 2000). Cell viability was expressed as the ratio between the viable cells for each treatment (i.e., EGCG milk and free EGCG) and the number of viable cells present in the corresponding control.

A cell viability test was used in combination with the sulforhodamine B (SRB) cytotoxicity assay to determine changes in cell proliferation, as previously reported with some minor modifications (Skehan et al., 1990; Vichai and Kirtikara, 2006). The SRB cytotoxicity assay is a colorimetric assay for the quantification of the total protein synthesis rate of cells in response to different concentrations of tea catechin. Sulforhodamine $\mathrm{B}$ is an anionic dye that binds to synthesized proteins. The fixed dye, measured photometrically after solubilization, correlates with protein synthesis and with cell proliferation (Vichai, and Kirtikara, 2006).

For proliferation assays, cells were seeded at a density of $2 \times 10^{3}$ cells per well in clear 96 -well plates and allowed to grow and attach for $24 \mathrm{~h}$; afterward, the medium was changed and then the cells were subsequently incubated for $24 \mathrm{~h}$ with different concentrations of free EGCG and EGCG milk samples [0.5 to $5 \mathrm{mg} / \mathrm{mL}$ of EGCG in the water or milk (see Milk Sample Preparation section for details)]. Control samples were also tested, either with medium only (for free EGCG) or with milk with no EGCG (for EGCG milk samples). Each sample was diluted in medium at a ratio of 1:6 (sample:medium, vol/vol). After $24 \mathrm{~h}$ of incubation, the cells were fixed with TCA and stained with SRB dye for $30 \mathrm{~min}$. The SRB was then removed and cultures were quickly rinsed with $1 \%$ acetic acid to remove unbound dye. After drying, the bound dye was solubilized with $10 \mathrm{~m} M$ Tris base ( $\mathrm{pH}$ 10.5). The absorbance was measured using an automated 96-well plate reader (multi-mode microplate reader, Synergy HT model; BioTek Instruments Inc., Winooski, VT) 
at a wavelength of $570 \mathrm{~nm}$. The results are reported as percentage proliferation, relative to their own control.

\section{Statistical Analysis}

The results presented are the averages of at least 3 independent experiments. At least 5 measurements per replicate were carried out. The mean values, standard deviations, and statistical differences were evaluated using ANOVA. All statistics were performed by using $\mathrm{R}$ software (R Project for Statistical Computing version 2.15.1; http://www.r-project.org/).

\section{RESULTS AND DISCUSSION}

This study focused on the effect of the milk matrix on the antiproliferative properties of EGCG on HT-29 colon cancer cells. Figure 1 shows EGCG encapsulated in the native casein micelles, as a function of the initial added amount of EGCG to skim milk. Studies using HPLC and small-angle x-ray scattering (SAXS) have shown that at a concentration of around $2.5 \mathrm{mg}$ of EGCG $/ \mathrm{mL}$ of milk, most of the tea catechin is associated with the colloidal phase of the micelles and saturation is reached (Shukla et al., 2009; Haratifar and Corredig, 2014). Therefore, for the cell cytotoxicity and proliferation assays, EGCG concentrations below saturation $(0.2$ and $0.5 \mathrm{mg} / \mathrm{mL})$, at saturation $(2.5 \mathrm{mg} /$ $\mathrm{mL}$ ), and above saturation $(5 \mathrm{mg} / \mathrm{mL})$ were used.

Figure 2 illustrates the differences in the viability of HT-29 cancer cells after $24 \mathrm{~h}$ of incubation with different concentrations of EGCG. Epigallocatechin gallate

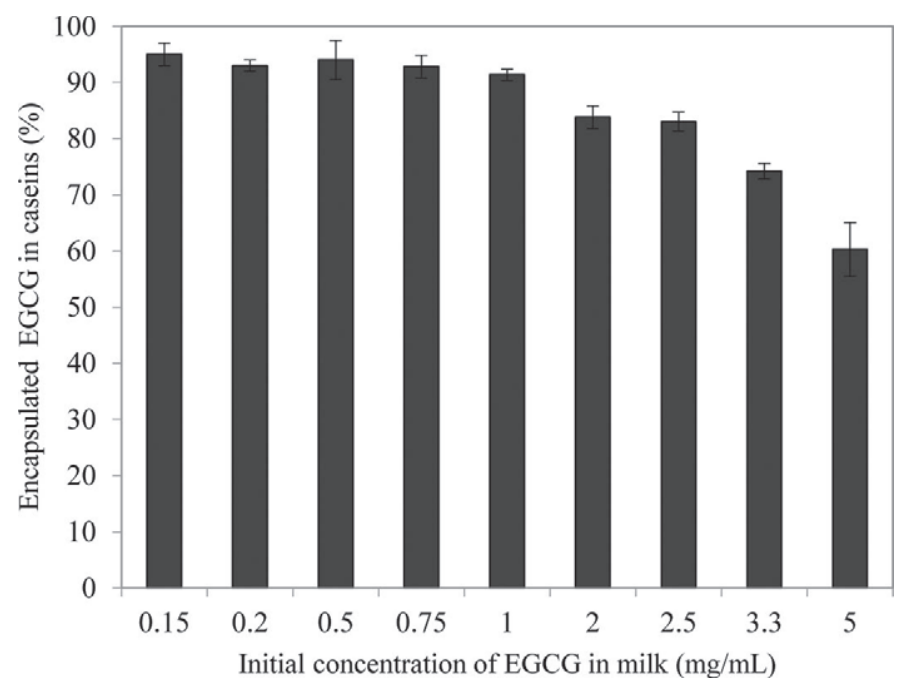

Figure 1. Amount of epigallocatechin gallate (EGCG) associated with the casein micelles in skim milk as a function of the initial concentration of EGCG in milk. Results are the average of 3 independent experiments and error bars represent SD.

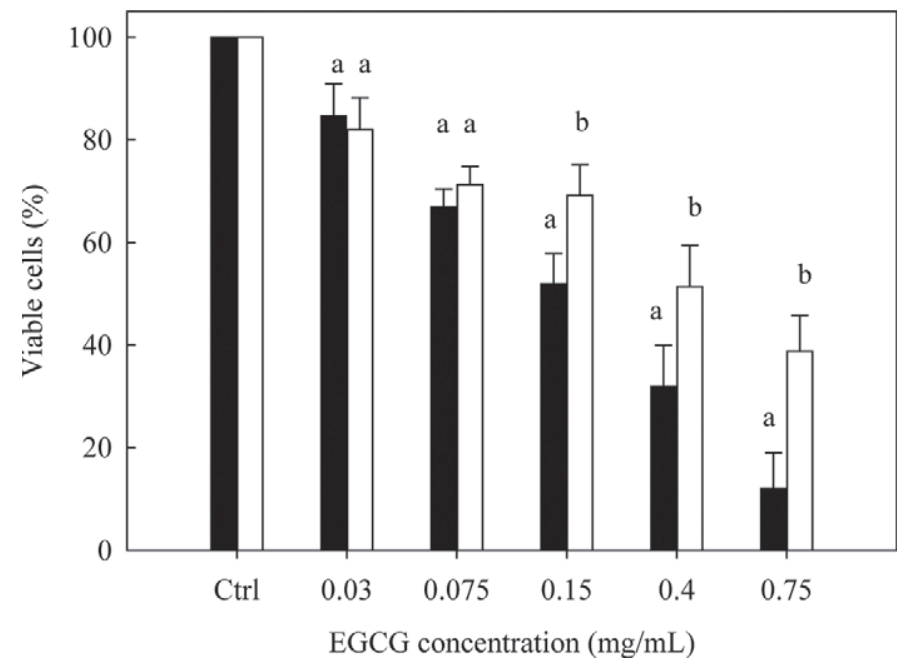

Figure 2. Viable cells after 24-h exposure to isolated epigallocatechin gallate (EGCG; solid bars) and EGCG encapsulated in casein micelles. All samples were diluted in medium in a 1:6 (sample:medium) ratio. The control used for free EGCG was medium without EGCG and the control used for of EGCG milk fractions was milk without EGCG. Values are the averages of at least 3 replicates and error bars represent SD. Within each concentration of EGCG, different letters (a and b) indicate statistically significant differences at $P<0.05$.

was either dispersed in water or nanoencapsulated in casein micelles (dispersed in milk). The final concentrations of EGCG in the wells (Figure 2) were 0.03, 0.075, $0.15,0.4$, and $0.75 \mathrm{mg} / \mathrm{mL}$, corresponding $0.2,0.5,1$, 2.5 , and $5 \mathrm{mg}$ of EGCG/mL in the original milk. The viability of the cells exposed to unencapsulated EGCG after $24 \mathrm{~h}$ of incubation (Figure 2, solid bars) decreased as a function of the amount of EGCG present, in full agreement with published studies using similar concentrations of EGCG (Salucci et al., 2002; Bazinet et al., 2010). When the cells were exposed to the mixture of EGCG milk samples (Figure 2; empty bars), the same trend was observed, with a decrease in viability with increasing EGCG.

Whereas at concentrations $<0.15 \mathrm{mg} / \mathrm{mL}$, no differences were observed in viability between free EGCG and encapsulated EGCG, at higher concentrations, above saturation, the viability of cells treated with milk was significantly higher than that of samples treated with water. This difference is related to the change in the medium composition and not to the presence of encapsulated/unencapsulated EGCG. The medium that is used as the control is Dulbecco's modified Eagle's medium supplemented only with fetal bovine serum and L-glutamine (as mentioned in the Materials and Methods section); however, the control for EGCG milk fractions is milk. Milk is known to be a natural, multicomponent and nutrient-rich beverage that contains many minerals and vitamins that can act as growth factors for the cells. 
To better identify the effect of the milk matrix and the concentration dependence of EGCG, the antiproliferative effect of EGCG on HT-29 cancer cells was studied using EGCG milk serum samples, EGCG whey samples, as well as EGCG milk samples. The milk serum and milk whey were separately mixed with EGCG and then exposed to the HT-29 cells, enabling us to see the effects of each component on cell proliferation.

The results are summarized in Figure 3. When EGCG was added (Figure 3, solid bars), even at very low concentrations (i.e., $\leq 0.02 \mathrm{mg} / \mathrm{mL}$ of medium) a significant decrease in cell proliferation was observed. At higher concentrations (i.e., $\geq 0.03 \mathrm{mg} / \mathrm{mL}$ of medium, corresponding to $\geq 0.2 \mathrm{mg} / \mathrm{mL}$ of milk), the effect on cell proliferation seemed to reach a plateau.

The same trend in the proliferation of the HT-29 colon cancer cells was seen when they were exposed to different concentrations of the EGCG milk samples. Figure 3 compares the proliferation of the cells incubated with EGCG dispersed in serum, milk whey, or skim milk (i.e., nanoencapsulated). In all cases, as the EGCG concentration increased, a decrease in cancer cell proliferation occurred, eventually plateauing at high concentrations. Although at higher concentrations of EGCG (i.e., $\geq 0.15 \mathrm{mg} / \mathrm{mL}$ of medium, corresponding to $\geq 1 \mathrm{mg}$ of $\mathrm{EGCG} / \mathrm{mL}$ of milk), no significant differences were noted in the antiproliferative activity of EGCG $(P>0.05)$, whether free or present in a milk matrix, the bioefficacy of free EGCG seemed to be affected in the presence of milk mixtures; as at low concentrations $(<0.015 \mathrm{mg} / \mathrm{mL})$, the extent of proliferation differed. This could not be attributed to the encapsulation of EGCG in casein micelles (Figure 3C), as the same effect was noted also for EGCG in milk serum (Figure 3A) and in milk whey (Figure 3B). This effect was probably caused by differences in medium composition, as milk serum, milk whey, and skim milk all contained growth factors not present in the water used to resuspend EGCG.

At about $0.03 \mathrm{mg} / \mathrm{mL}$ (corresponding to $0.2 \mathrm{mg} / \mathrm{mL}$ of milk), a significantly higher proliferation was noted for the cells treated with EGCG in skim milk, compared with EGCG in whey, milk serum, or the control. Hence, the effect of the interactions between tea catechin and caseins may still be apparent, as the EGCG milk fractions reach a plateau with some delay compared with the EGCG whey and EGCG milk serum (permeate) fractions. When comparing the estimated half maximal inhibitory concentration $\left(\mathrm{IC}_{50}\right)$ values $[0.01,0.016$, 0.018 , and $0.02 \mathrm{mg} / \mathrm{mL}$ for free EGCG, EGCG whey, EGCG milk serum, and EGCG milk (caseins), respectively], it could be hypothesized that this decrease in the apparent bioefficacy may be caused by the complexes formed between EGCG and casein micelles.

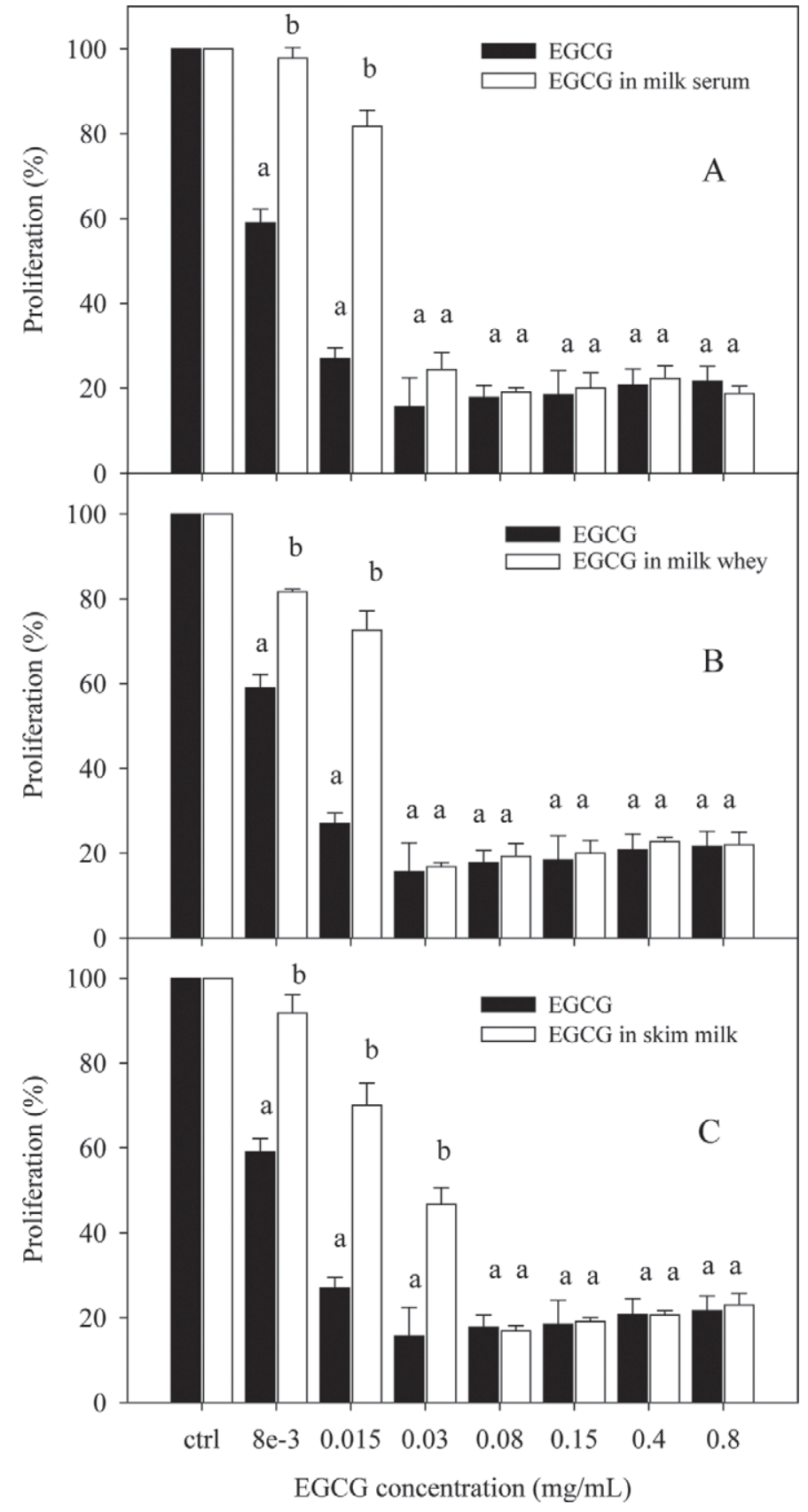

Figure 3. Proliferation of HT-29 cells exposed to isolated epigallocatechin gallate (EGCG; solid bars) or EGCG in milk serum (permeate; A), milk whey (B), or encapsulated with the casein micelles in skim milk (C). Values are the averages of at least 3 independent experiments and error bars represent SD. Within each concentration of EGCG, different letters ( $a$ and b) indicate statistically significant differences at $P<0.05$.

Therefore, the strong interactions between EGCG and milk caseins may affect the ability of EGCG to inhibit the proliferation of the cancer cells.

Epigallocatechin gallate is one of the most extensively investigated phytochemicals. By modulating signal 
transduction pathways involved in cell proliferation, transformation, inflammation, apoptosis, metastasis and invasion, EGCG could potentially block various stages of carcinogenesis (Na and Surh, 2006). However, to exert their biological health benefits in vivo, polyphenols must be available and still active, even when present in a food matrix.

\section{CONCLUSIONS}

This study showed that the binding of EGCG to the casein micelles did not affect the bioefficacy of EGCG and cell uptake at concentrations higher than $0.03 \mathrm{mg}$ of EGCG $/ \mathrm{mL}$ of skim milk. Cell proliferation results showed that the EGCG-milk complexes were able to significantly decrease the proliferation of HT-29 cancer cells in a manner similar to that of free EGCG. It is important to note, though, that the present studies were carried out on fresh EGCG. Mixed systems may ensure better stability of tea catechins in storage and during digestion, ultimately improving their bioefficacy.

\section{ACKNOWLEDGMENTS}

This work was funded by the Natural Sciences and Engineering Council of Canada (Ottawa, ON, Canada) and the Ontario Dairy Council (Mississauga, ON, Canada). The authors thank DSM Nutritional Products (Montreal, QC, Canada) for donating the tea catechin samples.

\section{REFERENCES}

Araújo, J. R., P. Gonçalves, and F. Martel. 2011. Chemopreventive effect of dietary polyphenols in colorectal cancer cell lines. Nutr. Res. 31:77-87. http://dx.doi.org/10.1016/j.nutres.2011.01.006.

Arts, M. J. T. J., G. R. M. M. Haenen, L. C. Wilms, S. A. J. N. Beetstra, C. G. M. Heijnen, H.-P. Voss, and A. Bast. 2002. Interactions between flavonoids and proteins: Effect on the total antioxidant capacity. J. Agric. Food Chem. 50:1184-1187.

Bazinet, L., M. Araya-Farias, A. Doyen, D. Trudel, and B. Têtu. 2010. Effect of process unit operations and long-term storage on catechin contents in EGCG-enriched tea drink. Food Res. Int. 43:16921701.

Bennick, A. 2002. Interaction of plant polyphenols with salivary proteins. Crit. Rev. Oral Biol. Med. 13:184-196.

Bohin, M. C., J.-P. Vincken, H. T. W. M. van der Hijden, and H. Gruppen. 2012. Efficacy of food proteins as carriers for flavonoids. J. Agric. Food Chem. 60:4136-4143. dx.doi.org/10.1021/jf205292r|.

Chen, C., G. Shen, V. Hebbar, R. Hu, E. D. Owuor, and A.-N. T. Kong. 2003. Epigallocatechin-3-gallate-induced stress signals in HT-29 human colon adenocarcinoma cells. Carcinogenesis 24:1369-1378. http://dx.doi.org/10.1093/carcin/bgg091.

Du, G.-J., Z. Zhang, X.-D. Wen, C. Yu, T. Calway, C.-S. Yuan, and C.-Z. Wang. 2012. Epigallocatechin gallate (EGCG) is the most effective cancer chemopreventive polyphenol in green tea. Nutrients 4:1679-1691. http://dx.doi.org/10.3390/nu4111679.

Dubeau, S., G. Samson, and H.-A. Tajmir-Riahi. 2010. Dual effect of milk on the antioxidant capacity of green, Darjeeling, and English breakfast teas. Food Chem. 122:539-545. http://dx.doi. org/10.1016/j.foodchem.2010.03.005.
Ehrich, M., and L. Sharova. 2000. In vitro methods for detecting cytotoxicity. Curr. Protoc. Toxicol. 3:2.6.1-2.6.27.

Ferruzzi, M. G. 2010. The influence of beverage composition on delivery of phenolic compounds from coffee and tea. Physiol. Behav. 100:33-41. http://dx.doi.org/10.1016/j.physbeh.2010.01.035.

Ferruzzi, M. G., N. Bordenave, and B. R. Hamaker. 2012. Does flavor impact function? Potential consequences of polyphenol-protein interactions in delivery and bioactivity of flavan-3-ols from foods. Physiol. Behav. 107:591-597. http://dx.doi.org/10.1016/j.physbeh.2012.02.020.

Ferruzzi, M. G., and R. J. Green. 2006. Analysis of catechins from milk-tea beverages by enzyme assisted extraction followed by high performance liquid chromatography. J. Agric. Food Chem. 99:484-491. http://dx.doi.org/10.1016/j.foodchem.2005.08.010.

González de Mejía, E., Y. S. Song, C. I. Heck, and M. Ramírez-Mares. 2010. Yerba mate tea (Ilex paraguariensis): Phenolics, antioxidant capacity and in vitro inhibition of colon cancer cell proliferation. J. Funct. Foods 2:23-34. http://dx.doi.org/10.1016/j. jff.2009.12.003.

Green, R. J., A. S. Murphy, B. Schulz, B. A. Watkins, and M. G. Ferruzzi. 2007. Common tea formulations modulate in vitro digestive recovery of green tea catechins. Mol. Nutr. Food Res. 51:11521162. http://dx.doi.org/10.1002/mnfr.200700086.

Haratifar, S., and M. Corredig. 2014. Interactions between tea catechins and casein micelles and their impact on renneting functionality. Food Chem. 143:27-32.

Hofmann, T., A. Glabasnia, B. Schwarz, K. N. Wisman, K. A. Gangwer, and A. E. Hagerman. 2006. Protein binding and astringent taste of a polymeric procyanidin, 1,2,3,4,6-penta- $O$-galloyl- $\beta$-Dglucopyranose, castalagin and grandinin. J. Agric. Food Chem. 54:9503-9509. http://dx.doi.org/10.1021/jf062272c.

Hong, J., H. Lu, X. Meng, J.-H. Ryu, Y. Hara, and C. S. Yang. 2002. Stability, cellular uptake, biotransformation, and efflux of tea polyphenol epigallocatechin-3-gallate in HT-29 human colon adenocarcinoma cells. Cancer Res. 62:7241-7246.

Kartsova, L. A., and A. V. Alekseeva. 2008. Effect of milk caseins on the concentration of polyphenolic compounds in tea. J. Anal. Chem. 63:1107-1111. http://dx.doi.org/10.1134/S1061934808110154.

Keogh, J. B., J. McInerney, and P. M. Clifton. 2007. The effect of milk protein on the bioavailability of cocoa polyphenols. J. Food Sci. 72:S230-S233.

Kyle, J. A. M., P. C. Morrice, G. McNeill, and G. G. Duthie. 2007. Effects of infusion time and addition of milk on content and absorption of polyphenols from black tea. J. Agric. Food Chem. 55:4889-4894. http://dx.doi.org/10.1021/jf070351y.

Langley-Evans, S. C. 2000. Consumption of black tea elicits an increase in plasma antioxidant potential in humans. Int. J. Food Sci. Nutr. 51:309-315.

Leenen, R., A. J. Roodenburg, L. B. Tijburg, and S. A. Wiseman. 2000. A single dose of tea with or without milk increases plasma antioxidant activity in humans. Eur. J. Clin. Nutr. 54:87-92.

Lesschaeve, I., and A. C. Noble. 2005. Polyphenols: Factors influencing their sensory properties and their effects on food and beverage preferences. Am. J. Clin. Nutr. 81:330S-335S.

Livney, Y. D. 2010. Milk proteins as vehicles for bioactives. Curr. Opin. Colloid Interface Sci. 15:73-83. http://dx.doi.org/10.1016/j. cocis.2009.11.002.

Luck, G., H. Liao, N. J. Murray, H. R. Grimmer, E. E. Warminski, M. P. Williamson, T. H. Lilley, and E. Haslam. 1994. Polyphenols, astringency and proline-rich proteins. Phytochemistry 37:357-371.

Na, H.-K., and Y.-J. Surh. 2006. Intracellular signaling network as a prime chemopreventive target of (-)-epigallocatechin gallate. Mol. Nutr. Food Res. 50:152-159. http://dx.doi.org/10.1002/ mnfr.200500154.

Ozdal, T., E. Capanoglu, and F. Altay. 2013. A review on proteinphenolic interactions and associated changes. Food Res. Int. 51:954-970.

Papadopoulou, A., and R. A. Frazier. 2004. Characterization of protein-polyphenol interactions. Trends Food Sci. Technol. 15:186190. http://dx.doi.org/10.1016/j.tifs.2003.09.017 
Pascal, C., C. Poncet-Legrand, B. Cabane, and A. Vernhet. 2008. Aggregation of a proline-rich protein induced by epigallocatechin gallate and condensed tannins: Effect of protein glycosylation. J. Agric. Food Chem. 56:6724-6732.

Rahimi Yazdi, S., and M. Corredig. 2012. Heating of milk alters the binding of curcumin to casein micelles. A fluorescence spectroscopy study. Food Chem. 132:1143-1149. http://dx.doi.org/10.1016/j. foodchem.2011.11.019.

Rodriguez del Angel, C., and D. G. Dalgleish. 2006. Structures and some properties of soluble protein complexes formed by the heating of reconstituted skim milk powder. Food Res. Int. 39:472-479. http://dx.doi.org/10.1016/j.foodres.2005.09.010.

Sahu, A., N. Kasoju, and U. Bora. 2008. Fluorescence study of the curcumin casein micelle complexation and its application as a drug nanocarrier to cancer cells. Biomacromolecules 9:2905-2912. http://dx.doi.org/10.1021/bm800683f.

Salucci, M., L. A. Stivala, G. Maiani, R. Bugianesi, and V. Vannini. 2002. Flavonoids uptake and their effect on cell cycle of human adenocarcinoma cells. Br. J. Cancer 86:1645-1651.

Saura-Calixto, F., J. Serrano, and I. Goñi. 2007. Intake and bioaccessibility of total polyphenols in a whole diet. Food Chem. 101:492501. http://dx.doi.org/10.1016/j.foodchem.2006.02.006.

Schwarz, B., and T. Hofmann. 2008. Is there a direct relationship between oral astringency and human salivary protein binding? Eur. Food Res. Technol. 227:1693-1698. http://dx.doi.org/10.1007/ s00217-008-0895-x.

Semo, E., E. Kesselman, D. Danino, and Y. D. Livney. 2007. Casein micelle as a natural nano-capsular vehicle for nutraceuticals. Food Hydrocoll. 21:936-942. http://dx.doi.org/10.1016/j.foodhyd.2006.09.006.

Shpigelman, A., G. Israeli, and Y. D. Livney. 2010. Thermally-induced protein polyphenol co-assemblies: Beta lactoglobulin-based nanocomplexes as protective nanovehicles for EGCG. Food Hydrocoll. 24:735-743. http://dx.doi.org/10.1016/j.foodhyd.2012.01.016.

Shukla, A., T. Narayanan, and D. Zanchi. 2009. Structure of casein micelles and their complexation with tannins. Soft Matter 5:28842888. http://dx.doi.org/10.1039/b903103k.

Skehan, P., R. Storeng, D. Scudiero, A. Monks, J. McMahon, D. Vistica, J. T. Warren, H. Bokesch, S. Kenney, and M. R. Boyd. 1990. New colorimetric cytotoxicity assay for anticancer-drug screening. J. Natl. Cancer Inst. 82:1107-1112.
Song, J., H. Xu, F. Liu, and L. Feng. 2012. Tea and cognitive health in late life: Current evidence and future directions. J. Nutr. Health Aging 16:31-34.

Vaidyanathan, J. B., and T. Walle. 2003. Cellular uptake and efflux of the tea flavonoid (-)-epicatechin-3-gallate in the human intestinal cell line Caco-2. J. Pharmacol. Exp. Ther. 307:745-752. http:// dx.doi.org/10.1124/jpet.103.054296.

Vichai, V., and K. Kirtikara. 2006. Sulforhodamine B colorimetric assay for cytotoxicity screening. Nat. Protoc. 1:1112-1116.

Visioli, F., C.A. De La Lastra, C. Andres-Lacueva, M. Aviram, C. Calhau, A. Cassano, N. D'Archivio, A. Faria, G. Favé, V. Fogliano, R. Llorach, P. Vitaglione, M. Zoratti, and M. Edeas. 2011. Polyphenols and human health: A prospectus. Crit. Rev. Food Sci. Nutr. 51:524-546. doi.org/10.1080/10408391003698677.

Wang, Z.-M., B. Zhou, Y.-S. Wang, Q.-Y. Gong, Q.-M. Wang, J.-J Yan, W. Gao, and L.-S. Wang. 2011. Black and green tea consumption and the risk of coronary artery disease: A meta-analysis. Am. J. Clin. Nutr. 93:506-515.

Yang, C. S., S. Sang, J. D. Lambert, Z. Hou, J. Ju, and G. Lu. 2006. Possible mechanisms of the cancer preventive activities of green tea. Mol. Nutr. Food Res. 50:170-175. http://dx.doi.org/10.1002/ mnfr.200500105.

Yang, C. S., S. Sang, J. D. Lambert, and M. J. Lee. 2008. Bioavailability issues in studying the health effects of plant polyphenolic compounds. Mol. Nutr. Food Res. 52(Suppl. 1):S139-S151. http:// dx.doi.org/10.1002/mnfr.200700234.

Yang, C. S., X. Wang, G. X. Li, Z. Yang, F. Guan, and H. Jin 2011. Cancer prevention by tea: Evidence from laboratory studies. Pharmacol. Res. 64:113-122. http://dx.doi.org/10.1016/j. phrs.2011.03.001

Yang, C. S., X. Wang, G. Lu, and S. C. Picinich. 2009. Cancer prevention by tea: Animal studies, molecular mechanisms and human relevance. Nat. Rev. Cancer 9:429-439. http://dx.doi.org/10.1038/ nrc2641.

Yuan, J.-M., C. Sun, and L. M. Butler. 2011. Tea and cancer prevention: Epidemiological studies. Pharmacol. Res. 64:123-135. http://dx.doi.org/10.1016/j.phrs.2011.03.002.

Zaveri, N. T. 2006. Green tea and its polyphenolic catechins: Medicinal uses in cancer and noncancer applications. Life Sci. 78:2073-2080. http://dx.doi.org/10.1016/j.lfs.2005.12.006. 